Інженери А.В. Гречко, О.Є. Німенко, канд. техн. наук Т.В. Шелейко (ДП «УкрНДІВ»)

Engineers A.V. Grechko, A.E. Nishchenko, cand. of techn. sciences T.V. Sheleyko

\title{
РОЗЧІПНИЙ ПРИСТРІЙ
}

\section{UNCOUPLER DEVICE}

\section{Представив д-р техн. наук, професор I.Е. Мартинов}

\begin{abstract}
Постановка проблеми. Подальше удосконалення гальмівних систем, 3 урахуванням прийнятого напрямку на створення високошвидкісного транспорту, потребує для їх ефективного та якісного дослідження підвищення точності визначення гальмівних шляхів
\end{abstract} досліджуваного вагона та використання в процесі поїзних гальмівних випробувань методу «кидання» замість методу послідовних гальмувань, недоліком якого, крім тривалого часу проведення випробувань, $є$ необхідність перерахування гальмівних характеристик дослідного зчепу на характеристики дослідного вагона, що зумовлює велику похибку вимірювань у визначенні гальмівного коефіцієнта $[1,2]$.

Метод «кидання» $є$ найбільш точним і достовірним 3 існуючих на сьогодні методів експериментального визначення гальмівного шляху, однак його застосування через високий ступінь ризику 3 погляду безпеки руху вимагає обов'язкового огородження всієї ділянки колії, де проводяться випробування, оскільки «кинутий» вагон до повної зупинки рухається самостійно, без керування, під дією тільки своєї гальмівної сили.

Виконання досліду за методом «кидання» потребує, крім злагодженої роботи усього персоналу, що бере участь у випробуваннях, застосування більш досконалого випробувального обладнання, зокрема, пристрою для автоматичного розчеплення автозчепу вагона-лабораторії 3 наступним перекриттям кінцевого крана для запобігання витоку стисненого повітря 3 гальмівної системи після відокремлення дослідного вагона (далі - розчіпний пристрій).

Аналіз останніх досліджень i публікацій. Недоліками відомих на даний час пристроїв для розчеплення одиниць рухомого складу [3-5] є, насамперед, стаціонарне розташування їх розчіпного механізму відносно залізничної колії, що не дозволяе використовувати їх під час руху вагонів на магістральних шляхах у момент, коли виникає в цьому потреба. Крім того, жоден з них не в змозі забезпечити автоматичного перекриття кінцевого крана після спрацювання розчіпного механізму, що $€$ важливим, коли необхідно забезпечити негальмування складу поїзда, що рухається.

Мета статті. Розглянути конструкцію та принцип роботи пристрою для автоматичного розчеплення одиниць рухомого складу, який створений співробітниками Державного підприємства «Український науково-дослідний інститут вагонобудування» та використовується ними під час проведення поїзних гальмівних випробувань за методом «кидання».

Конструкція та принцип роботи пристрою. Розчіпний пристрій складається 3 пульта управління (I), пристрою розчеплення автозчепу (II) і пристрою перекриття кінцевого крана (III) та виконаний як окрема електропневматична система, живлення стисненим повітрям якої здійснюється через роз'єднувальний кран (РК) від гальмівної магістралі вагона-лабораторії, де він встановлений (див. рисунок). 

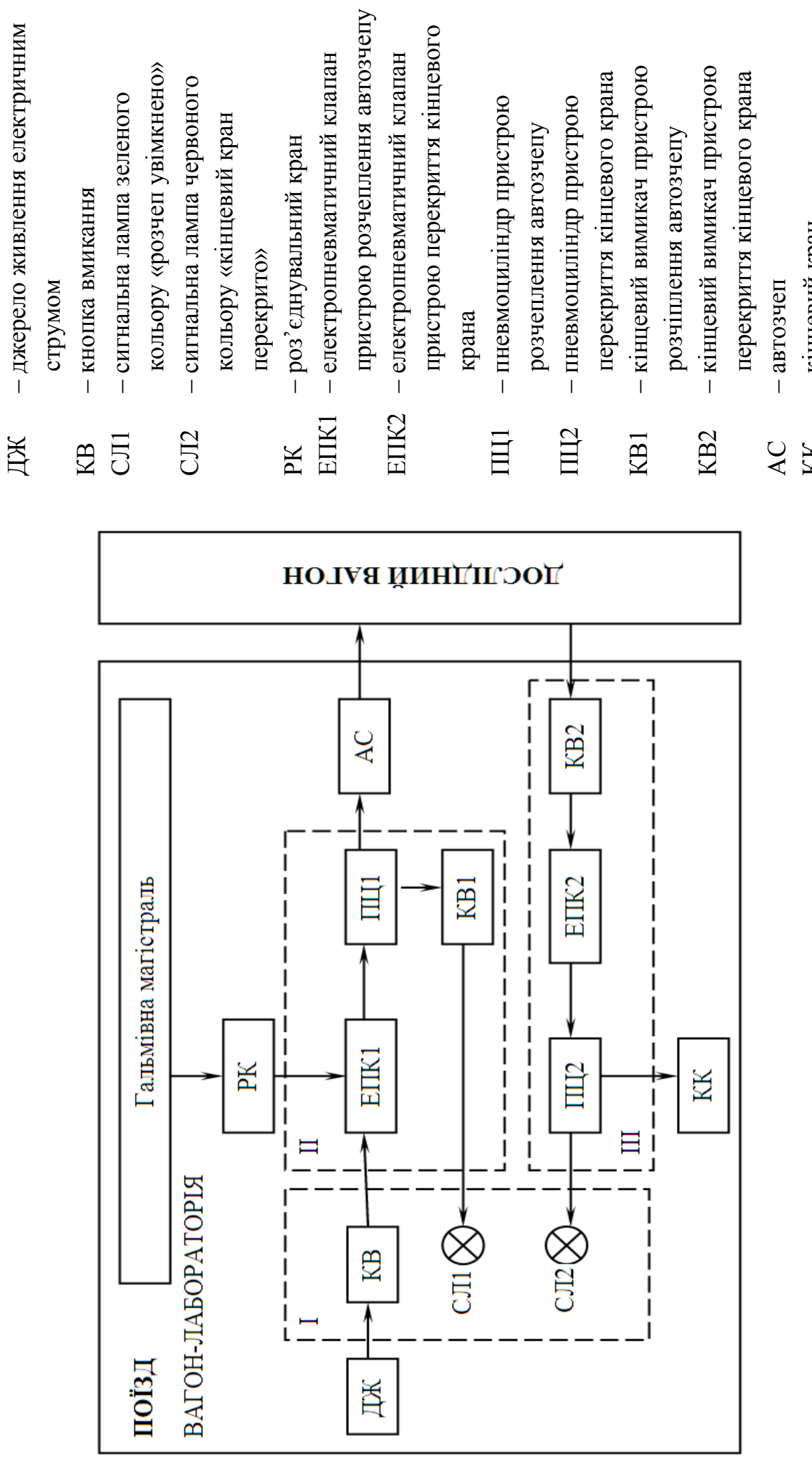

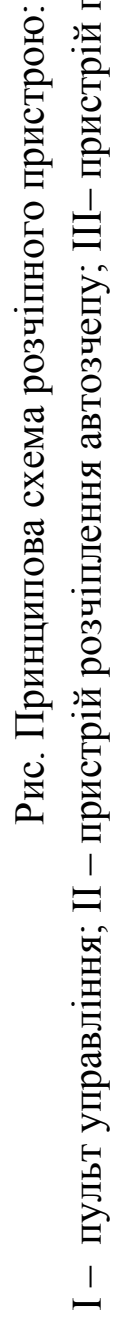


Пульт управління (I) призначений для дистанційного електричного керування механізмом розчеплення вагона-лабораторії i дослідного вагона. До складу пульта управління (I) входять електричні кола керування електропневматичними клапанами пристроїв розчеплення автозчепу і перекриття кінцевого крана, а також сигналізації щодо їх стану. Корпус пульта управління забезпечує необхідну фіксацію його складових частин та захист від зовнішніх механічних факторів. На передню панель пульта управління виведені кнопка вмикання розчіпного пристрою (КВ) та сигнальні лампи (СЛ1 зелена - «розчеп увімкнено», СЛ2 червона - «кінцевий кран перекрито»).

Пристрій розчеплення автозчепу (II) складається 3 електропневматичного клапана (ЕПК1), пневмоциліндра (ПЦ1) та кінцевого вимикача автозчепу (КВ1) і дає можливість дистанційно здійснювати розчеплення автозчепу між вагономлабораторією і випробувальним вагоном в процесі поїзних випробувань гальмівної системи останнього.

Пневмоциліндр (ПЦ1) пристрою служить для передачі тягового зусилля механізму розчеплення автозчепу вагоналабораторії. Для цього він закріплений на планці (кронштейнах) під вагоном до рами останнього, а шток його поршня з'єднаний через ланцюг 3 валиком підйомника на корпусі автозчепу (AC). Керування пневмоциліндром (ПЦ1) здійснюється потоком стисненого повітря, що надходить 3 повітропроводу від гальмівної магістралі через роз'єднувальний кран (РК) та електропневматичний клапан (ЕПК1) за електричним сигналом від пульта управління (I) у разі приведення оператором в дію кнопки вмикання (КВ) розчіпного пристрою. Хід штоку поршня пневмоциліндра (ПЦ1) відрегульований таким чином, аби замок автозчепу (AC) потрапляв у карман його корпусу, а сам шток поршня вмикав кінцевий вимикач (КВ1) автозчепу. Останнє супроводжується світловим сигналом зеленої сигнальної лампи (СЛ1) «розчеп увімкнено».

Пристрій перекриття кінцевого крана (III) складається 3 пневмоциліндра (ПЦ2), електропневматичного клапана (ЕПК2) та кінцевого вимикача (КВ2) і дає можливість дистанційно здійснювати перекриття кінцевого крана (КК) з метою запобігання витоку стисненого повітря 3 гальмівної магістралі вагона-лабораторії після відокремлення від нього випробувального вагона в процесі поїзних випробувань гальмівної системи останнього.

Пневмоциліндр (ПЦ2) пристрою служить для передачі зусилля на рукоятку кінцевого крана (КК) 3 наступним його перекриттям. Для цього він встановлений у торцевій частині вагона з боку перехідної площадки, а шток його поршня з'єднаний за допомогою сталевого тросика із рукояткою кінцевого крана (КК). Керування пневмоциліндром (ПЦ2) здійснюється потоком стисненого повітря, що надходить 3 повітропроводу від електропневматичного клапана (ЕПК2) за електричним сигналом від кінцевого вимикача (КВ2), який приводиться в дію після замикання контактів через вислизання пластини завдяки тросику, що 3'єднує іiі з дослідним вагоном. При цьому відбувається перекриття кінцевого крана (КК), про що свідчить світло червоної сигнальної лампи (СЛ2). Система відрегульована таким чином, що перекриття кінцевого крана (КК) здійснюється до моменту роз'єднання рукавів зчеплених вагонів.

Випробувальне обладнання (складові частини пристрою разом 3 кабелями i трубопроводами) змонтовано таким чином, що його робота не перешкоджає нормальному функціонуванню інших елементів вагона, та надійно закріплене аби виключити можливість їхнього падіння, ушкодження або самовільного спрацювання під час руху.

Порядок роботи 3 пристроєм. Перед початком проведення поїзних випробувань 
пульт управління (I) пристрою підключають до джерела живлення, а сам пристрій - за допомогою роз'єднувального крана (РК) до гальмівної магістралі вагоналабораторії.

Виконують перевірку роботоздатності пристрою розчеплення автозчепу (II) шляхом натиснення кнопки вмикання (КВ) на пульті управління (I). Має відбутися розчеплення автозчепу (AC) і спалахування зеленої сигнальної лампи (СЛ1).

Перевірку роботоздатності пристрою перекриття кінцевого крана (III) здійснюють шляхом висмикування пластини $з$ тросиком і замикання контактів кінцевого вимикача (КВ2). Має відбутися перекриття кінцевого крана (КК) вагоналабораторії і спалахування червоної сигнальної лампи (СЛ2).

Остаточну перевірку розчіпного пристрою виконують під час проведення пробного досліду відповідно до методики випробувань гальмівної системи за методом «кидання» [6]: розігнаний до швидкості 40 км/год випробувальний вагон від'єднується від вагона-лабораторії шляхом натискання кнопки вмикання (КВ) розчіпного пристрою на пульті управління
(I). Якщо система відрегульована правильно, послідовно відбувається розчеплення автозчепу (АС), спалахування зеленої сигнальної лампи (СЛ1), перекриття кінцевого крана (КК), спалахування червоної сигнальної лампи (СЛ2), роз'єднання рукавів та відокремлення дослідного вагона 3 його наступним гальмуванням. Подальші випробування проводять аналогічно відповідно до затвердженої методики проведення поїзних гальмівних випробувань.

По закінченні випробувань пульт управління (I) відключають від джерела живлення, a розчіпний пристрій за допомогою роз'єднувального крана (РК) від гальмівної магістралі вагоналабораторії.

Висновок. Пристрій дозволяе здійснювати автоматичне розчеплення автозчепу та перекриття кінцевого крана вагона-лабораторії i може використовуватися під час проведення поїзних випробувань гальм залізничного рухомого складу за методом «кидання», коли розігнаний до заданої швидкості дослідний вагон необхідно відокремити від дослідного поїзда.

\section{Список літератури}

1. Грищенко, С.Г. Методика гальмівних випробувань залізничного немоторного рухомого складу [Текст] / С.Г. Грищенко, В.І Кашуба, П.Ю. Крамаренко, В.П. Степанова // Залізничний транспорт України. - 2009. - № 1. - С. 12-14.

2. Кузьмина, Е.И. Методика экспериментального определения тормозных характеристик вагонов [Текст] / Е.И. Кузьмина, А.М. Морозов // Вестник ВНИИЖТ. - 1975. - № 3. - C. 17-23.

3. А.С. 221017 СРСР, МКИ В $61 \mathrm{G}$ 7/04. Устройство для расцепки вагонов [Текст] / Д.В. Прохоров (СССР). - 1115239/27-11; заявл. 18.11.66; опубл. 01.0-7.68, Бюл. № 12.

4. Устройство для расцепки вагонов [Текст]: пат. 92638 РФ, МПК В61G7/02 (2006.01) / Ададуров С.Е., Розенберг Е.Н., Моров Э.Н. [и др.]; патентообладатель ОАО «НИИАС». № 2009145159/22; заявл. 07.12.09; опубл. 27.03.10.

5. Устройство для автоматической расцепки автосцепок движущихся железнодорожных вагонов [Текст]: пат. 2410262 РФ, МПК В61G7/04 (2006.01) / Москвичев О.В., Суетин В.В.,Кузнецов А.Г. [и др.]; патентообладатель СамГУПС. №2009143451/11; заявл. 24.11.09; опубл. 27.01.11.

6. Методика та порядок проведення гальмівних випробувань вагонів методом «кидання» [Текст]. - Кременчук: УкрНДІВ, 2002. - 17 с. 
Ключові слова: автозчеп, вагон-лабораторія, дослідний вагон, метод «кидання», поїзні випробування, гальмівна система.

\section{Анотаціï}

Розглянуто конструкцію та принцип роботи пристрою для автоматичного розчеплення автозчепу вагона-лабораторії з наступним перекриттям кінцевого крана після відокремлення дослідного вагона в процесі проведення поїзних випробувань гальмівної системи за методом «кидання».

Рассмотрена конструкция и принцип работы устройства для автоматической расцепки автосцепки вагона-лаборатории с последующим перекрытием концевого крана после отсоединения опытного вагона в процессе проведения поездных испытаний тормозной системы методом «бросания».

Design and operation principle of the automatic coupler releasing mechanism of the research car with the subsequent shutdown of the end valve after decoupling of the research car during dynamic tests of the brake system by the method of throwing were investigated 